\title{
Alberta Northern Leopard Frog Recovery Plan 2005-2010
}
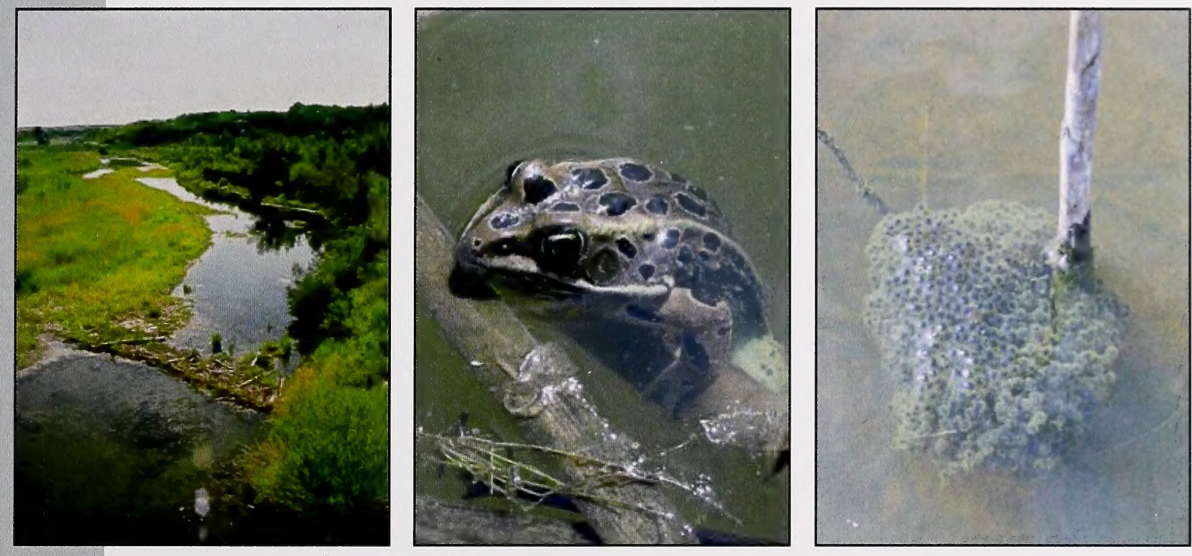

Alberta Species at Risk Recovery Plan No. 7

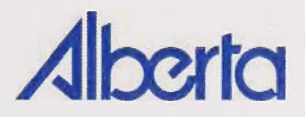


Digitized by the Internet Archive in 2016 


\section{Alberta Northern Leopard Frog Recovery Plan 2005-2010}

Prepared by:

The Alberta Northern Leopard Frog Recovery Team

David R. C. Prescott (Team Leader), Alberta Fish and Wildlife Division

Michael Barr, Ducks Unlimited Canada

Laura Campbell, Alberta Agriculture, Food and Rural Development

Craig Horner, Alberta Beef Producers

Gerry Haekel, Alberta Public Lands and Forests Division

D. Edward Hofman, Alberta Fish and Wildlife Division

Kris Kendell, Alberta Conservation Association

Dug Major, Special Areas Board

Heather D. Wheeliker, Alberta Environment

Douglas P. Whiteside, Calgary Zoo

\section{December 2005}

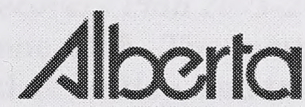

Sustainable Resource

Development 
Publication No.: I/230

ISBN: 0-7785-4513-X (Printed Edition)

ISBN: 0-7785-4514-8 (On-line Edition)

ISSN: $1702-4897$ (Printed Edition)

ISSN: $1702-4900$ (On-line Edition)

Cover photos: Kris Kendell (left), Dave Prescott (centre and right)

For copies of this report, contact:

Information Centre - Publications

Alberta Sustainable Resource Development

Main Floor, Great West Life Building

9920 - 108 Street

Edmonton, Alberta, Canada T5K 2M4

Telephone: (780) 422-2079

OR

Visit the Species at Risk Program web site at:

http://www3.gov.ab.ca/srd/fw/speciesatrisk/

This publication may be cited as:

Alberta Northern Leopard Frog Recovery Team. 2005. Alberta Northern Leopard Frog Recovery Plan, 2005-2010. Alberta Sustainable Resource Development, Fish and Wildlife Division, Alberta Species at Risk Recovery Plan No. 7. Edmonton, AB. 26 pp. 


\section{PREFACE}

Albertans are fortunate to share their province with a diverse variety of wild species. Populations of most species of plants and animals are healthy and secure. However, a small number of species are either naturally rare or are now imperilled because of human activities. Recovery plans establish a basis for cooperation among government and stakeholders to ensure these species and populations are restored or maintained for future generations.

Alberta's commitment to the Accord for the Protection of Species at Risk and to the National Framework for the Conservation of Species at Risk, combined with requirements established under Alberta's Wildlife Act and the federal Species at Risk Act, has resulted in the development of a provincial recovery program. The overall goal of the recovery program is to restore species identified as Threatened or Endangered to viable, naturally self-sustaining populations within Alberta.

Alberta species at risk recovery plans are prepared under the supervision of the Fish and Wildlife Division, Alberta Sustainable Resource Development. These recovery plans are prepared by recovery teams composed of a variety of stakeholders including conservation organizations, industry, landowners, resource users, universities, government agencies and others. Membership is by invitation from the Director of Wildlife Management, and includes representation from the diversity of interests unique to each species and circumstance. Conservation and management of these species continues during preparation of the recovery plan.

Recovery plans include three main sections: background information that highlights the species' biology, population trends and threats; a recovery section that outlines goals, objectives, and strategies to address the threats; and an action plan that profiles priority actions required to maintain or restore the Threatened or Endangered species.

These plans are provided by the recovery team as advice to the Minister of Sustainable Resource Development (the Minister; the Department) and to all Albertans. The Department, other provincial departments, as appropriate, and Alberta's Endangered Species Conservation Committee review draft recovery plans, and provide recommendations to the Minister. In addition, an opportunity for review by the public is provided.

Approved plans are a summary of the Department's commitment to work with involved stakeholders to coordinate and implement conservation actions necessary to restore or maintain these species. Recovery plans are "living" documents and are revised as conditions change or circumstances warrant. Implementation of each recovery plan is subject to the availability of resources, from within and from outside government.

The Alberta Northern Leopard Frog Recovery Plan 2005-2010 was reviewed by the Endangered Species Conservation Committee in June 2005. The committee subsequently recommended to the Minister that the plan be approved as written, and implemented. On December 16, 2005, the Minister approved the recovery plan and directed the Department to implement the plan to guide the recovery program for northern leopard frog in Alberta. 


\section{TABLE OF CONTENTS}

PREFACE iii

LIST OF FIGURES

ACKNOWLEDGEMENTS

EXECUTIVE SUMMARY

vii

1.0 INTRODUCTION

1.1 Provincial and Federal Status

1.2 Recovery Team

2.0 SPECIES BIOLOGY

2.1 Life History

2.2 Habitat

2.3 Population Distribution and Trends in Alberta

3.0 THREATS AND LIMITING FACTORS

3.1 Climate

3.2 Disease

3.3 Habitat Loss and Fragmentation

3.4 Habitat Alteration

3.5 Water Quality

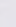

3.6 Water Management Activities __ 7

3.7 Road Kills __ 7

3.8 Harvest __ 8

3.9 Introduction of Game Fish or Exotic Species ___ 8

4.0 RESEARCH NEEDS_ 8

5.0 RECENT RECOVERY AND CONSERVATION EFFORTS ___ 9

6.0 RECOVERY STRATEGY _ 10

6.1 Biological and Technical Feasibility of Recovery ___ 10

6.2 Guiding Principles _ـ 11

6.3 Recovery Goal ___ 11

6.4 Recovery Objectives _ـ 12

6.5 Strategies for Recovery ___ 12

$\begin{array}{ll}7.0 & \text { ACTION PLAN _ } 13\end{array}$

7.1 Population and Habitat Monitoring ___ 13

7.2 Reintroduction __ 13

7.3 Habitat Management and Protection __ 14 
7.4 Information and Outreach

7.5 Research

7.6 Plan Management and Administration

7.7 Resource Acquisition

8.0 IMPLEMENTATION SCHEDULE AND COSTS

9.0 SOCIO-ECONOMIC CONSIDERATIONS

\section{LIST OF FIGURES}

Figure 1. Historical distribution, and distribution since 2000 of northern leopard frogs in Alberta

Figure 2. Major river basins and sub-basins where management of northern leopard frogs will occur in Alberta 


\section{ACKNOWLEDGEMENTS}

The members of the Alberta Northern Leopard Frog Recovery Team thank their respective organizations for providing in-kind support for the preparation of this plan. Most of the background information and formatting of this plan was done by Dr. Kelley Kissner, whose efforts are greatly appreciated. We also thank Steve Brechtel and Sue Cotterill (Alberta Fish and Wildlife Division), Ian Rudland (Alberta Environment), and Carol Barsky (Canadian Association of Petroleum Producers) for providing comments on an earlier draft. Preparation of the plan was funded by the Species at Risk Program of Alberta Sustainable Resource Development. 


\section{EXECUTIVE SUMMARY}

The northern leopard frog (Rana pipiens) is a medium-sized frog with powerful hind legs and extensively webbed hind feet that are well adapted for jumping and swimming. Northern leopard frogs are semi-aquatic, spending time in both aquatic and terrestrial environments. Distinct habitats are used for breeding, foraging and overwintering. Widespread declines of this species have occurred throughout North America. Historically, northern leopard frogs were widely distributed and locally abundant in the Grassland, Foothills, and Parkland Natural Regions of central and southern Alberta and in the extreme northeastern region of Alberta. However, abrupt and dramatic population declines were noted in the late 1970s and early 1980s. Since that time, the abundance of northern leopard frogs in Alberta has been low and the species has been extirpated from many parts of its historical range.

In February 2004, the Minister of Sustainable Resource Development maintained the listing of the northern leopard frog as Threatened under Alberta's Wildlife Act. This designation was based on a decline in the number of populations and in the area of occupancy, fragmentation and decline of populations combined with a small area of occupancy, and limited population dispersal and exchange capabilities with adjacent populations. Along with this listing, the Minister issued an initial Conservation Action Statement that formally initiated recovery actions in the province. This statement specified that a recovery plan would be prepared within 24 months of its listing and that sufficient new resources should be made available to support population monitoring and assessment, and recovery planning. Furthermore, the action statement advised that Alberta Sustainable Resource Development should enhance programs to collect data on population size, distribution, trends, and habitat availability in Alberta.

The Alberta Northern Leopard Frog Recovery Plan, 2005-2010 has been prepared by the Alberta Northern Leopard Frog Recovery Team to guide the management of this Threatened species over the next five years. The ultimate goal of this initiative is to achieve well-distributed, self-sustaining populations of leopard frogs throughout their historical range in Alberta. A long-term objective $(>25$ years) is to ensure that there are at least two self-sustaining populations of northern leopard frogs in each subdrainage of all major river drainages in southern Alberta, including three areas where frogs have been extirpated (Battle River, North Saskatchewan and upper Red Deer basins). During the life of this plan, the Team aims to protect known sites from anthropogenic threats, improve our knowledge of northern leopard frog populations in the province, reintroduce frogs to at least 10 sites in southern Alberta, increase awareness of the species and its conservation, and monitor the success of reintroduction efforts. These objectives will be achieved by a series of actions grouped into seven strategic areas: (1) population and habitat monitoring, (2) reintroduction, (3) habitat management and protection, (4) information and outreach, (5) research, (6) plan management and administration, and (7) resource acquisition. Specific actions in each of these areas are detailed, along with anticipated costs and lead agencies.

The overall cost of the actions detailed in the recovery plan is $\$ 655,000$ over five years, including both cash and essential "in-kind" support. A variety of agencies will be invited to participate in the funding and implementation of recovery initiatives. 


\subsection{INTRODUCTION}

\subsection{Provincial and Federal Status}

In February 2004, the Minister of Sustainable Resource Development approved the maintenance of the listing of northern leopard frog (Rana pipiens) as Threatened in Schedule 6 of Alberta's Wildlife Act, based on the recommendation from the Endangered Species Conservation Committee (ESCC). This designation was based on a decline in the number of populations and in the area of occupancy, fragmentation and decline of populations combined with a small area of occupancy, and limited population dispersal and exchange capabilities of this species. The action statement specified that a recovery plan would be prepared within 24 months of the species' listing and that sufficient new resources should be made available to support population monitoring and assessment, and recovery planning. Furthermore, the action statement advised that Alberta Sustainable Resource Development should enhance programs to collect data on population size, distribution, trends, and habitat availability in Alberta.

The national status of the western boreal/prairie population of the northern leopard frog was evaluated in April 1998 and again in November 2002 and was designated as Special Concern by the Committee on the Status of Endangered Wildlife in Canada (COSEWIC 2004). This designation reflects the widespread contraction of this species range on the western prairies for which the causes remain unknown, increasing isolation of the remaining populations, and the lack of recolonization of areas formally occupied. As a species of Special Concern, a management plan must be developed for this population of northern leopard frogs by 2008 .

Significant declines in northern leopard frog populations have occurred across much of western Canada and the western United States. The British Columbia population (southern mountain population) is listed as Endangered by the Committee on the Status of Endangered Wildlife in Canada (COSEWIC 2004). The species is also on the provincial Red List and is listed as Endangered in British Columbia's Wildlife Act. In Washington and Oregon, the northern leopard frog is listed as listed as S1 ("critically imperilled"; NatureServe 2005). In Idaho, Montana and Wyoming, the northern leopard frog is ranked as S3 ("vulnerable"; NatureServe 2005).

\subsection{Recovery Team}

The Alberta Northern Leopard Frog Recovery Team was initiated by the Minister of Sustainable Resource Development, and receives operational guidance and approval from the Director of Wildlife Management. The Team's primary responsibility is to facilitate, monitor and evaluate the conservation and recovery of northern leopard frogs in Alberta. It provides expert advice to the Minister on the management of this species in the province. The Team is also responsible for writing, updating and guiding the implementation of the recovery plan. The Team does not implement recovery actions directly, although Team members and their associated organizations will participate in the recovery initiatives. Because of the multi-stakeholder nature of recovery issues, Team membership includes representatives of parties likely to affect or to be affected by recovery actions. The Team will encourage and facilitate the involvement of all interested 
parties in the recovery of northern leopard frogs in Alberta, whenever possible, and will annually report on the progress of the recovery program.

\subsection{SPECIES BIOLOGY}

\subsection{Life History}

The northern leopard frog is a medium-sized frog (ca. 60 to $110 \mathrm{~mm}$ snout-vent length) with powerful hind legs and extensively webbed hind feet that are well adapted for jumping and swimming (Hine et al. 1981, Nace et al. 1996, Russell and Bauer 2000). Northern leopard frogs are identified by their smooth skin, by a pair of continuous white- or cream-coloured ridges extending from behind their eyes to their lower backs, and by the presence of numerous dark spots with light borders on their backs, legs, and sides (Russell and Bauer 2000, Kendell 2002b, Alberta Sustainable Resource Development 2003). The background colour of the skin is typically green, but may be brown or tan. Females are typically larger than males (Hine et al. 1981, Nace et al. 1996, Russell and Bauer 2000).

Northern leopard frogs are semi-aquatic, spending time in both aquatic and terrestrial environments. During the winter, leopard frogs hibernate underwater in waterbodies that do not freeze solid (Hine et al. 1981, Russell and Bauer 2000). Emergence from hibernation occurs shortly after ice begins to melt (Merrell 1977, Wershler 1992a). After emergence, adult frogs travel up to $1.6 \mathrm{~km}$ to different waterbodies to breed (Hine et al. 1981, Wershler 1991a, Souder 2000). In Alberta, breeding typically occurs between April and late June (Wershler 1992a, Kendell 2002a). In any given year, breeding may be limited to a few days to a few weeks. Breeding is initiated by males that vocalize to attract females. Breeding females deposit 600 7000 eggs in masses that are attached to emergent vegetation (Corn and Livo 1989). Hatching is dependent on water temperature but may occur as soon as five to nine days after egg laying (Hine et al. 1981). Metamorphosis occurs 60 to 90 days after hatching (Wershler 1991a). At metamorphosis, frogs switch from being herbivorous to carnivorous, foraging primarily on small invertebrates (e.g., insects, spiders), and occasionally on small birds, snakes, frogs and fish (Moore and Strickland 1954, Rittschof 1975, Russell and Bauer 2000). Newly transformed frogs can disperse up to $8 \mathrm{~km}$ from natal ponds (Dole 1971, Seburn et al. 1997). After breeding, adults migrate (up to $1.6 \mathrm{~km}$ ) to forage in riparian or upland habitats.

Life spans of wild northern leopard frogs rarely exceed four to five years, but captive frogs may live as long as nine years (Froom 1982, Leclair and Castanet 1987, Russell and Bauer 2000). Annual mortality rates of adults and immature frogs are high. Estimates of adult mortality are ca. $60 \%$ (Merrell and Rodell 1968), while overwinter mortality of newly transformed frogs may exceed 93\% (Yaremko 1996). 


\section{$\underline{2.2 \text { Habitat }}$}

Three distinct habitat types (breeding, foraging and overwintering) are required by northern leopard frogs. Given the limited dispersal capabilities of this species, it is important that these habitats are available within close proximity to each other (Pope et al. 2000).

\section{Breeding Habitat}

Breeding occurs in the shallow, warm waters of a variety of waterbodies including marshes, sloughs, springs, ditches, dugouts, borrow pits, beaver ponds, lakes, and slow-moving waters of streams and rivers (Cook 1966, 1984, Cottonwood Consultants 1986, Merrell 1977, Roberts 1981, Hine et al. 1981, Wershler 1992a, Seburn and Seburn 1998, Kendell 2002b). Preferred waterbodies also have some degree of permanence such that water is present until after transformation of tadpoles (Merrell and Rodell 1968), are non-acidic (pH: 6.5-8.5, Nace et al. 1996), and contain no predatory fish (Merrell and Rodell 1968). The presence of emergent vegetation is also important for protective cover and as a substrate to attach egg masses (Wershler 1991a, 1992a, Kendell 2002b).

\section{Foraging Habitat}

After breeding and transformation, adults, sub-adults and young-of-the-year can move considerable distances (up to $2 \mathrm{~km}$ ) to summer foraging areas. These areas are usually moist habitats such as meadows, pastures, scrublands, or drainage or irrigation ditches (Hine et al. 1981, Merrell 1977, Wershler 1991 a, Seburn 1994). Northern leopard frogs tend to avoid areas that are heavily wooded (Merrell 1977, but see Seburn 1994) or that have sparse cover (e.g., heavily grazed fields, lawns, cultivated fields; Dole 1971, Merrell 1977, Hine et al. 1981).

\section{Overwintering Habitat}

Waterbodies used for overwintering by northern leopard frogs are cold $\left(\mathrm{ca} .<4^{\circ} \mathrm{C}\right)$, well oxygenated (7-10 ppm) and do not freeze solid (Hine et al. 1981, Cunjak 1986, Nace et al. 1996). These characteristics are typically associated with deeper, permanent waterbodies including springs, streams, creeks, rivers, ponds and lakes. Typically, different waterbodies are used for breeding and overwintering activities (Souder 2000). Information on the characteristics and location of overwintering sites in Alberta is very limited.

\subsection{Population Distribution and Trends in Alberta}

Historically, northern leopard frogs were widely distributed and locally abundant in the Grassland, Foothills, and Parkland Natural Regions ${ }^{1}$ of central and southern Alberta, and in the extreme northeastern region of Alberta (Figure 1; Kendell 2002c, Alberta Sustainable Resource Development 2003). However, abrupt and dramatic population declines were noted in the late 1970s and early 1980s (Roberts 1981, 1987). Since that time, the abundance of leopard frogs has been low and many formerly occupied sites are now vacant (Figure 1). In 1990 and 1991 a province-wide survey was undertaken to determine the distribution of northern leopard frogs in Alberta. Twenty-four sites were found to be occupied (Wershler 1991a, b). More intensive local surveys, focussing on a small number of these sites were conducted in these years, and in several

\footnotetext{
${ }^{1}$ See Alberta Environmental Protection (1994) for description of Natural Regions of Alberta.
} 


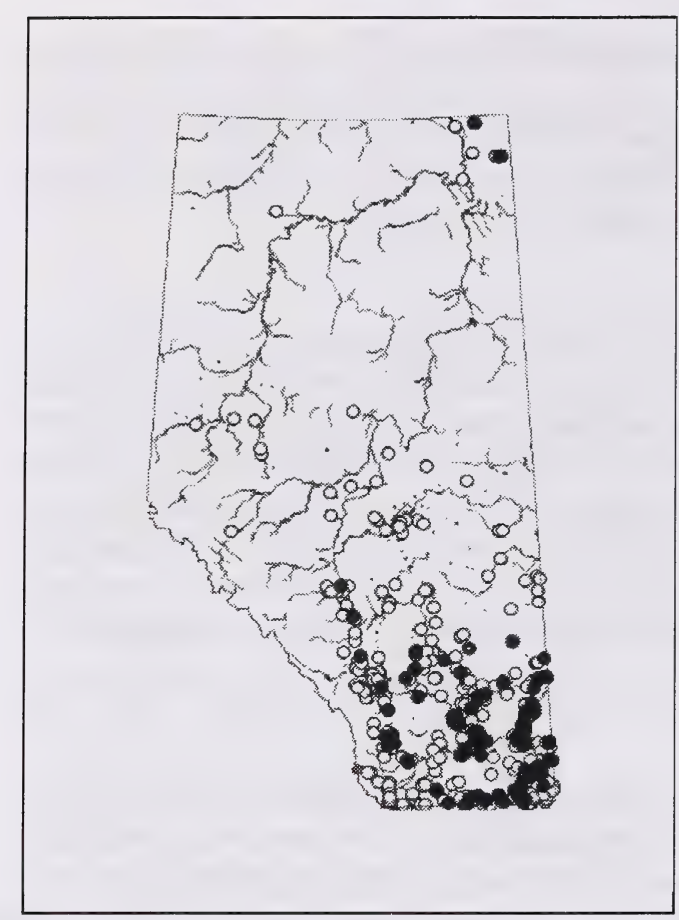

Figure 1. Historical distribution (light circles), and distribution since 2000 (dark circles) of northern leopard frogs in Alberta.

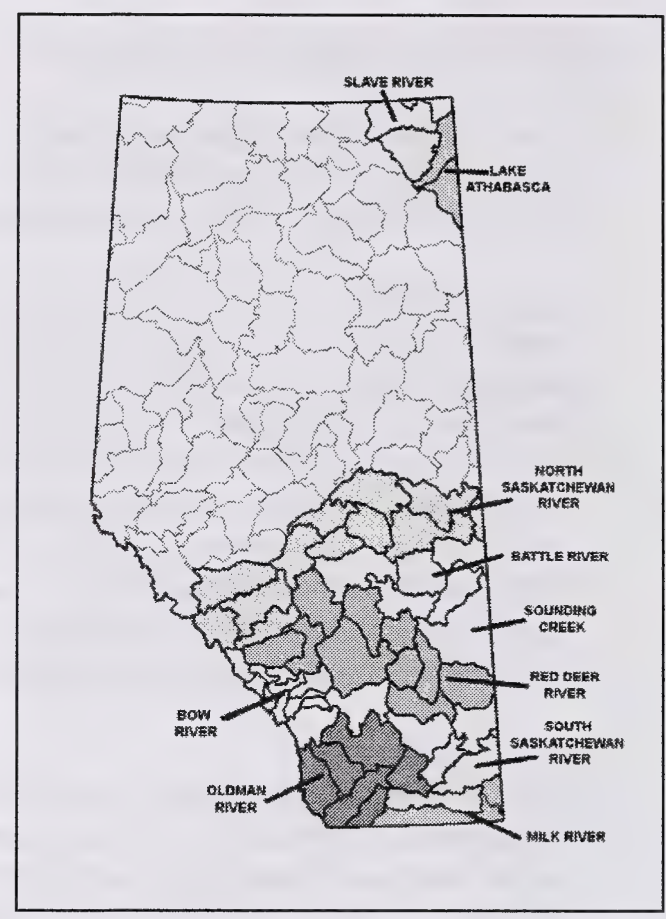

Figure 2. Major river basins and sub-basins where management of northern leopard frogs will occur in Alberta (following Alberta Environment).

subsequent years (e.g., Hofman 1991, 1992, 1994a, b, 1995, Wershler 1992b). A second province-wide survey was conducted in 2000 and 2001 (Kendell 2002c). In total, 269 historical sites were surveyed; northern leopard frogs were found at only 54 of these sites. Most occupied sites were associated with major river drainages including the lower Red Deer, Oldman, South Saskatchewan, lower Bow and the Milk Rivers (see Figure 2 for locations of major river basins). Northern leopard frogs were also found in the extreme northeastern region of Alberta. Since this last province-wide survey, several northern leopard frog populations have been monitored during provincial population surveys of amphibians such as the Researching Amphibian Numbers in Alberta (RANA) project (Wilkinson and Hanus 2003, Wilkinson and Kempin 2004), the Alberta Volunteer Amphibian Monitoring Program (see Alberta Sustainable Resource Development 2003), and during reintroduction efforts targeted at northern leopard frogs (Kendell 2001, 2002a, 2004, Romanchuk 2003; see Section 5.0, below).

Population size and trends are difficult to determine for this species based on available survey information. Population surveys usually cover a large geographic area, allowing sites to be checked only once during the survey and limiting the time spent at each location. Single-site surveys may fail to detect individuals. Furthermore, amphibian populations can fluctuate widely among years (Pechmann et al. 1991) and individuals may be more likely to be detected (e.g., vocalize) at certain times of day (Cook 1984). 


\subsection{THREATS AND LIMITING FACTORS}

Dramatic declines in population sizes have been observed for numerous amphibian populations around the world, similar to that observed for northern leopard frogs in Alberta and across North America (Blaustein and Wake 1990). The specific reasons for these declines are not known but may be due to a number of natural and human caused factors. Factors thought to be associated with northern leopard frog declines in Alberta are listed below (following Alberta Sustainable Resource Development 2003). These factors may act independently, may interact, or may act simultaneously to threaten the frog populations in Alberta. Several of the natural limiting factors (e.g., climate) are unlikely to be mitigated by actions outlined in this recovery plan.

\subsection{Climate}

Climatic factors, such as drought, can have a major influence on northern leopard frog populations (Merrell 1977, Corn and Fogleman 1984, Koch et al. 1996). In drought years, habitat for frogs will be lost and local populations may be extirpated. Drought conditions were associated with a decline in amphibian populations in southern Alberta in the 1930s (Fowler 1935). Drought conditions were also prevalent in southern Alberta in the late 1970s and 1980s, suggesting a possible link between climatic conditions and the abrupt decline of this species in Alberta beginning in the late 1970s. Some biologists have dismissed this possibility because populations have been lost from many permanent waterbodies in Alberta that would not have been affected by drought (Roberts 1981, 1987, 1992, Wershler 1991a). Thus, climate has likely contributed to declines in population size, but it is unlikely to be the only factor.

Increasing ultraviolet (UV) radiation from a thinning ozone layer has also been associated with declines of amphibian populations. Embryo mortality has been attributed to UV radiation in the genus Rana (Blaustein et al. 1994). Northern leopard frogs lay their eggs close to the water surface, possibly increasing their susceptibility to UV radiation. UV radiation may also reduce resistance to disease and pathogens.

\subsection{Disease}

Northern leopard frogs and other amphibians are susceptible to diseases that may cause large numbers of mortalities (Daszak et al. 1999). Mass mortalities from diseases may be a natural phenomenon and/or may be related to a variety of environmental stressors. Infections by certain bacteria (most commonly Aeromonas hydrophilia) results in a condition referred to as "red-leg" that is nearly always fatal. This disease affects the kidneys and other organs of frogs and appears to be triggered by factors such as stress, injury, malnourishment or environmental conditions such as poor water quality (Nace et al. 1996, Kendell 2002b, Alberta Sustainable Resource Development 2003). Mortality and apparent population declines in northern leopard frogs have previously been associated with "red-leg" in North America (Gibbs et al. 1971, Hine et al. 1981, Koonz 1992). Fungal and viral infections such as Ranavirus and Herpesvirus have also been noted in northern leopard frogs and may contribute to mortality of adults or embyros (McKinnell 1973, Hunter et al. 1989, Alberta Sustainable Resource Development 2003). Two fungi, in particular, have been associated with large numbers of mortalities of amphibians.

Chytridiomycosis caused by the "chytrid" fungus (Batrachochytrium dendobatidis) was found on 
northern leopard frogs collected in Alberta (Alberta Sustainable Resource Development 2003.). Chytrids are ubiquitous fungi found in aquatic and moist habitats where they degrade cellulose, chitin and keratin. In amphibians, the parasitic chytrid degrades the keratin component of the skin, leading to excessive keratin production and sloughing of skin (Berger et al. 1999). Although the exact mechanism by which the fungus kills the host is unknown, it is postulated that either there is absorption of a fungal toxin, or there is damage to the skin that impairs cutaneous respiration. (Berger et al. 1998, Pessier et al. 1999). Factors affecting chytrid abundance include seasonal temperature changes, water $\mathrm{pH}$, light, nutrition and dissolved oxygen (Sparrow 1968). Saprolegniasis, associated with Saprolegnia ferax and S. parasitica, results from invasion of these fungi into wounds. S. ferax is a common pathogen of fish and their eggs. Although this species has not been found in Alberta, it has been associated with high mortality of northern leopard frog eggs in British Columbia (Alberta Sustainable Resource Development 2003). The introduction of fish into prairie waterbodies may facilitate the spread of this fungus. Resistance to infection by this fungus may decline with exposure to UV-B radiation (Keisecker and Blaustein 1995). The most well-described viral pathogen in northern leopard frogs is Lucke's tumor virus (a Herpesvirus), which causes tumors of the kidneys. The virus can also infect eggs and young embryos, which may result in tumor development during the adult stage (McKinnell and Carson 1997).

\section{$\underline{3.3 \text { Habitat Loss and Fragmentation }}$}

Habitat loss has been associated with declines of leopard frog populations in many areas of North America (Lannoo et al. 1994, Koch et al. 1996). In southern Alberta, drainage of wetlands for agricultural use has been extensive. In addition, Turner et al. (1987) estimated that almost $60 \%$ of basins, and approximately $80 \%$ of wetland margins in the prairies and parkland regions of Alberta were impacted by agricultural activities in the 1980s. Although the impact of these activities on the Alberta leopard frog population has not been estimated, it is likely that local extirpations have resulted from these activities (Alberta Sustainable Resource 2003).

Land-use activities may also fragment habitat for northern leopard frogs, resulting in areas of suitable habitat being separated by areas of unsuitable habitat. Habitat fragmentation may be a particular concern for frog populations because individuals migrate among a variety of habitats to fulfill various aspects of their life histories (Pope et al. 2000). Activities that act as barriers to migration could result in mortalities or local population extinctions. Habitat fragmentation may also disrupt dispersal of individuals among local populations (Pope et al. 2000), which could compromise the ability of the Alberta population to persist. Prior to the recent population decline, northern leopard frog populations in Alberta likely operated as a metapopulation, characterized by a collection of local populations residing in geographically isolated patches of suitable habitat. These local populations are typically subject to high rates of local extinctions from environmental or natural factors, but are re-colonized through dispersal of individuals among populations (Hanski and Gilpin 1991, Hanski 1998). Escalating habitat loss or fragmentation that increases isolation among local populations may limit the ability of individuals to disperse and re-colonize habitats, or may result in extinctions of local populations from reduced gene flow. Northern leopard frog populations may be particularly affected by fragmentation because they appear to have limited ability to disperse across large areas of unsuitable habitat (Kendell 2002a, Alberta Sustainable Resource Development 2003). 


\subsection{Habitat Alteration}

Some land-use activities may reduce suitability of habitat for northern leopard frogs. For example, intensive livestock activity, particularly in riparian habitat, could threaten frog populations in Alberta (Wershler 1991b). Disturbance from livestock may include reduced vegetative cover and diversity as a result of grazing and trampling, destruction or disturbance of egg masses, increased water turbidity and erosion that may affect tadpole development, and contamination of breeding and overwintering sites from livestock wastes. The presence of livestock has been noted at a number of sites used by northern leopard frogs in Alberta (Seburn 1992, Alberta Sustainable Resource Development 2003). Ungulates and livestock may have beneficial impacts on northern leopard frog populations by controlling non-native vegetation that may impact movement and foraging by frogs (Waye and Cooper 2001). Consequently, management of livestock activity may be used to improve riparian habitat for northern leopard frogs.

\subsection{Water Quality}

Northern leopard frogs carry out a number of activities in the water (including breeding, foraging, and overwintering), and have thin but well-vascularized skin that allows for cutaneous respiration. Consequently, northern leopard frogs are particularly sensitive to environmental contaminants or activities that impact water quality. As discussed above, livestock wastes can affect water quality by increasing nutrient levels and lowering oxygen levels (Alberta Sustainable Resource Development 2003). The use of pesticides and herbicides may also negatively impact frogs. Pesticides and herbicides have been associated with, or suspected in, observations of impaired development or malformations of frogs (e.g., Hayes et al. 2002, Johnson et al. 2002).

\subsection{Water Management Activities}

Projects that stabilize or alter water levels to enhance recreational opportunities or to improve habitat for other species (fish and birds) could impact northern leopard frog populations (Wershler 1991a). These activities could reduce habitat availability by reducing the amount of vegetation around wetlands. Furthermore, raising water levels (flooding) during the spring could dislodge egg masses from emergent vegetation, whereas lowering water levels prior to metamorphosis of tadpoles could result in mortality. These activities may also impact water quality, including temperature and oxygen levels.

Use of water for oil and gas and other land-use activities during the winter could also affect aquifers and reduce water levels, leading to freezing of overwintering ponds used by northern leopard frogs.

\section{$\underline{3.7 \text { Road Kills }}$}

When large numbers of frogs are migrating between breeding, foraging, and overwintering sites they may be at risk of mortality due to road kills (Fahrig et al. 1995). Road kills are not thought to be a major limiting factor for the Alberta population, but high road mortality has been noted in 
other parts of the species' range (Merrell 1977, Fahrig et al. 1995, Ashley and Robinson 1996). As habitat becomes increasingly fragmented by roads, this factor may become more important in Alberta.

\section{$\underline{3.8 \text { Harvest }}$}

Traditionally, northern leopard frogs were harvested commercially for research and teaching purposes (e.g., dissection), but this practice has been restricted for many years in Alberta (Alberta Sustainable Resource Development 2003). Leopard frogs have also been harvested as bait for recreational fishing and collected by children who enjoy raising frogs and tadpoles. These latter uses would not typically threaten the species, but given the status of the Alberta population, could contribute to further declines. As a Threatened species in the Wildlife Act, collection of northern leopard frogs is prohibited without a permit. However, some recreational collection undoubtedly still persists. Efforts to inform the public on the status of this species and its formal protection may help ensure that recreational collection is minimized.

\subsection{Introduction of Game Fish or Exotic Species}

Introduction of game fish to waterbodies could lead to increased predation of northern leopard frog adults or tadpoles (Emery et al. 1972) or may serve as vectors of parasites or pathogens (Keisecker et al. 2001). In other areas of North America, introduction of bullfrogs (Rana catesbeiana) have been associated with declines in leopard frog populations (Lannoo et al. 1994, Reichel and Flath 1995, Koch et al. 1996). Bullfrogs have yet to be introduced into Alberta and the effects of introductions of game fish on Alberta populations of northern leopard frogs are unknown but merit consideration (Alberta Sustainable Resource Development 2003).

\subsection{RESEARCH NEEDS}

The biology and ecology of northern leopard frogs are relatively well studied. Thus, research to facilitate the conservation and recovery of this species in Alberta should focus on monitoring of populations and habitat, and evaluating the effectiveness of recovery initiatives. Research should also continue on developing increasingly effective protocols for reintroduction and establishment of northern leopard frog populations. Genetic information collected from Alberta populations and populations from other jurisdictions should be used to help guide the reintroduction program (e.g., information on genetic diversity, local adaptations). Research tools such as geographic information systems (GIS) technology should be used to identify potential sites for translocation and to identify previously unknown sites that may support northern leopard frogs. All recovery activities will require the surveillance for, and possible study of, diseases that may affect provincial populations and reintroduction efforts. 


\subsection{RECENT RECOVERY AND CONSERVATION EFFORTS}

A variety of initiatives aimed at conserving leopard frogs, other amphibians, and their habitat in Alberta have been implemented since widespread declines of this species were noted in the province.

In 1989, Alberta Fish and Wildlife Division launched the "Have You Seen This Frog?" poster campaign to encourage reporting of northern leopard frog sightings by the public. Response to the program was favourable and provided important information on distribution of the species.

In 1992, the Alberta Volunteer Amphibian Monitoring Program (AVAMP) was initiated by a small group of volunteers in southern Alberta. In 1997, the AVAMP developed into a provincewide program that is delivered by the Alberta Conservation Association in partnership with Alberta Sustainable Resource Development. This is a volunteer-based program aimed at increasing public awareness of amphibians and collecting information on their occurrence in Alberta. Information is used to help in status determination, management, and potential recovery efforts for amphibians such as the northern leopard frog. As part of this program, a "Teachers Guide for the Alberta Amphibian Monitoring Program" has been developed to encourage participation of school children (Grades 5 and 6) in the program. Another teacher's guide, the "Northern Leopard Frog Teacher's Guide" was developed by Alberta Environment for Grades K to 3 to educate younger children about northern leopard frogs. This guide is based on an interactive story with information and activities on leopard frogs to facilitate learning.

In 1997, the "Researching Amphibian Numbers in Alberta (RANA)" project was initiated by the Alberta Conservation Association, Alberta Environment, and the University of Alberta, and is now coordinated by Alberta Sustainable Resource Development. The main objectives of this program are to collect long-term data on Alberta amphibian populations and to provide public education on conservation of amphibians and their habitats. The program remains in operation and annually monitors amphibian populations, including northern leopard frogs, at several sites across Alberta.

The recognition that increasing isolation of remaining northern leopard frog populations would limit their ability to naturally recolonize historic parts of their range provided the impetus for a reintroduction program in Alberta (Cottonwood Consultants 1986, Roberts 1987, 1991, 1992 , 1994, Wershler 1991a, Fisher 1999). The goal of this program has been to re-establish northern leopard frogs in the upper Red Deer and North Saskatchewan River drainages, encouraging natural dispersal of frogs downstream along these watersheds (Kendell 2001). In 1999, a pilot captive-rearing program was initiated at the Raven Brood Trout Station near Caroline (Wendlandt and Takats 1999). Confirmed observations of northern leopard frogs at release sites and evidence of breeding activity has provided some evidence of the success of this program and has led to its continuation. Between 1999 and 2004, more than 13,000 northern leopard frogs have been captive-reared at the Raven Brood Trout Station and released at three sites within the historical range of the species (Kendell 2004). Another program, focussing on the reintroduction of egg masses into suitable habitats around Magrath was initiated in 2003 (Romanchuk 2003). 
Several initiatives have been undertaken to manage habitat for northern leopard frogs. These include fencing of riparian habitat to prevent cattle damage at Prince's Spring, where a significant breeding population of frogs exists (Hofman 1992), development of provincial guidelines for industrial development near northern leopard frog breeding sites to mitigate potential disturbance associated with these developments (Alberta Fish and Wildlife Division 2001), and the development of beneficial management practices for amphibians as part of the Multi-Species at Risk Conservation Strategy for the Milk River Basin Program (Rangeland Conservation Service Ltd. 2004, Quinlan et al. 2004).

Several research projects have focussed on the biology and habitat requirements of northern leopard frogs in Alberta. Seburn et al. (1997) investigated the dispersal of young leopard frogs in the Cypress Hills. Butterworth (1999) reviewed the role of disease on amphibian declines and the potential impact of diseases on the re-establishment of amphibians. He also examined a protocol for the reintroduction of amphibians in order to prevent the introduction of diseases at relocation sites. Wendlandt (1999) researched habitat preferences of northern leopard frogs in Cypress Hills. Kendell (2000a) investigated winter physiology and ecology of northern leopard frogs to provide information on habitat use and behaviour of frogs during hibernation. Another study (Kendell 2000b) compared aquatic conditions (e.g., water quality) at occupied and formerly occupied sites, as well as potential reintroduction sites, to help understand use or potential use of these sites by frogs. Dalgleish (2001) investigated the feasibility of establishing a captive-rearing facility at the Calgary Zoo.

Finally, Alberta has cooperated in many national and international initiatives aimed at conservation and recovery of northern leopard frogs, including the National Frogwatch program and the Canadian Amphibian and Reptile Conservation Network.

\subsection{RECOVERY STRATEGY}

\subsection{Biological and Technical Feasibility of Recovery}

It is the belief of the Alberta Northern Leopard Frog Recovery Team that the recovery of northern leopard frogs is biologically and technically feasible. The biology and ecology of northern leopard frogs are well understood, which limits the amount of background work and information required to determine where conservation efforts should be focussed. Much of this work, including efforts to manage populations of northern leopard frogs, has been conducted in Alberta (see Section 5.0). The collective wisdom gained from this work provides a solid basis for the goals, strategies and actions contained in this recovery plan, and for optimism about the recovery of northern leopard frog populations in Alberta.

One of the primary tools for the recovery of northern leopard frog populations in Alberta is translocation into formerly occupied areas of the range. Attempts to reintroduce frogs in the province have been ongoing on a modest scale since the late 1990s, with some early indications of success (see Section 5.0). The presence of large and productive populations in some areas of the province (i.e., source populations for translocations), and the widespread availability of vacant but suitable habitat for introductions suggests that increased repatriation efforts are 
feasible. Furthermore, reintroduction programs for leopard frogs can be conducted at relatively low cost compared to reintroduction programs for other species. Reintroduction facilities and rearing ponds can be relatively simple in design and easy to maintain.

Public interest and support for conservation of northern leopard frogs has been high, increasing the potential for successful recovery of this species in Alberta. Management initiatives aimed at northern leopard frogs also complement numerous other habitat management initiatives in the province, and especially those that focus on the management and conservation of wetland or riparian habitats. Thus, management conflicts or competing goals of various conservation initiatives should not be an issue, which should increase cooperation by landholders and users.

\section{$\underline{6.2 \text { Guiding Principles }}$}

The recovery and management of northern leopard frogs in Alberta will be guided by the following principles:

- Recovery Team members believe that the recovery of the northern leopard frog is both desirable and achievable, and are committed to working together to achieve this goal.

- All land users and managers on northern leopard frog range, including all affected branches of government, will be strongly encouraged to share responsibility for and support the goal of northern leopard frog recovery.

- The Team recognizes that humans engage in activities that contribute to economic growth in areas where the northern leopard frog occurs. We will therefore work in a collaborative and cooperative manner with land managers, landowners, industry and other agencies to ensure, to the extent possible, that recovery initiatives are compatible with sustainable land uses.

- The loss of habitat and populations of the northern leopard frog is undesirable and preventable.

- Recovery actions will embrace an ecosystem (holistic) approach to management, whenever possible.

- Lack of information or scientific certainty should not impede implementation of actions believed to be necessary to achieve the goals of this recovery plan. Whenever possible, the collection of data and scientific study of northern leopard frogs and their management are desirable.

- The recovery process will be guided by the concept of adaptive management, whereby specific actions are implemented, evaluated, and improved upon on an iterative basis.

- Landowners, lessees, and other cooperators in the management of northern leopard frogs should be recognized for their contributions towards achieving recovery goals.

- Landowners will not be unduly affected by the costs associated with maintaining or enhancing northern leopard frog habitat, or other recovery measures.

\section{$\underline{6.3 \text { Recovery Goal }}$}

The goal of the Alberta Northern Leopard Frog Recovery Plan is to achieve well-distributed and self-sustaining populations of northern leopard frogs throughout their historical range in Alberta. 


\subsection{Recovery Objectives}

Long Term ( $>25$ year): Presence of at least two self-sustaining populations of northern leopard frogs in each sub-watershed of major drainage basins (Milk, Oldman, Bow, Red Deer, North Saskatchewan, South Saskatchewan, Battle, Sounding Creek, Slave and Lake Athabasca; see Figure 2) within the species historical range in Alberta. The long-term goal includes reintroduction of populations to three areas where northern leopard frogs have been extirpated (Battle River basin, North Saskatchewan River basin, and the upper portion of the Red Deer River basin).

Short Term (5 year):

- Implement appropriate management to protect all known, existing populations and their habitats against anthropogenic threats (to the extent possible).

- Improve knowledge of population size, distribution, trends, reproductive status, threats and habitat availability in Alberta.

- Reintroduce northern leopard frogs to at least 10 sites within their historical range in the Milk, Oldman, Bow, Red Deer, Sounding Creek and South Saskatchewan River basins of southern Alberta.

- Increase public awareness of leopard frogs and their conservation in Alberta.

- Monitor the progress of past and current reintroduction and management efforts.

\section{$\underline{6.5 \text { Strategies for Recovery }}$}

The goal and objectives of the Alberta Northern Leopard Frog Recovery Plan will be achieved by the implementation of seven distinct strategies, which will be pursued concurrently over a five-year period. Whenever possible, these strategies, and their associated actions, will be integrated with those of other species at risk recovery efforts in the province.

Population and Habitat Monitoring - all actions related to the monitoring of northern leopard frog populations in Alberta, including regular monitoring of known sites, assessment of reintroduction sites, and the search for new populations.

Reintroduction - all actions related to the re-establishment of northern leopard frogs in formerly occupied areas of the species' provincial range.

Habitat Management and Protection - all actions related to assessing and improving the quality and security of breeding, summering and wintering habitat for northern leopard frogs in Alberta. Existing tools, policies and processes that are applicable to the protection of habitat in Alberta will be used whenever possible.

Information and Outreach - all actions related to providing information and extension to landowners/lessees, industrial interests, recovery partners, and the general public about the conservation and management of the northern leopard frog in Alberta. The focus will be on preventing degradation or loss of habitat, gaining public assistance with finding new leopard frog 
populations, expanding awareness of conservation issues related to leopard frogs, and gaining support and participation in management initiatives.

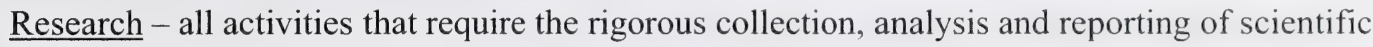
data that will yield information relevant to the management and recovery of northern leopard frog populations in Alberta.

Plan Management and Administration - all activities related to the operation of the Alberta Northern Leopard Frog Recovery Team and implementation of the Alberta Northern Leopard Frog Recovery Plan. A key element of this strategy is to build linkages with other provincial, national and international initiatives that will benefit northern leopard frog conservation in Alberta.

Resource Acquisition - all actions related to securing funding and other resources needed to support management actions.

\subsection{ACTION PLAN}

Actions designed to meet the objectives of the northern leopard frog recovery program are listed below for each strategy described in Section 6.0 (above). Specific timetable, costs, and lead agencies for each action are detailed in Section 8.0.

\subsection{Population and Habitat Monitoring}

1. Design and complete survey in 2005 of all sites ( 85$)$ known to be occupied by northern leopard frogs since 2000 , as well as reliable and geographically identifiable historical sites. This survey will provide a current status of the provincial population, and identify source populations and suitable habitat for subsequent reintroduction efforts.

2. Conduct late-summer surveys of all occupied sites (based on 2005 survey) and selected historical sites on a rotating 5-year cycle. A subset of sites will be visited each year.

3. Conduct annual spring inventories to identify specific breeding sites (sources of egg masses for reintroduction) at major breeding populations in watersheds where reintroductions are scheduled.

4. Conduct targeted surveys each year to search for previously unknown frog populations in areas where new information indicates possible or probable presence of northern leopard frogs.

\subsection{Reintroduction}

1. Based on the results of the 2005 inventory (see Section 7.1, Item \#1), develop a detailed strategy and protocol for the reintroduction of northern leopard frogs into vacant areas of their historical range in Alberta. The protocol will address sources of egg masses, intensity 
of egg collection, prioritization of watersheds/subwatersheds for reintroduction, criteria for selection of reintroduction sites, stocking frequency and intensity, education/outreach opportunities, and the desirability and feasibility of building captive breeding facilities to provide eggs for the program.

2. If determined to be desirable and feasible, establish a pilot breeding facility that would service at least one drainage where reintroductions are targeted.

3. Reintroduce egg masses (from sites identified in Section 7.1, Item \#3) to each of at least 10 currently unoccupied, yet suitable, sites (in addition to the four sites where introductions have recently occurred). Reintroductions will occur in at least two of the six major river basins in southern Alberta.

4. Assess the success of reintroductions conducted at four sites conducted between 1999 and 2004, and conduct annual assessments at all future release sites.

5. Develop a quantitative system for measuring the success of reintroductions based on evidence and magnitude of reproduction, population density relative to natural populations in Alberta, demographic attributes or other characteristics.

\subsection{Habitat Management and Protection}

1. Assess anthropogenic threats, biotic and abiotic characteristics, and ownership of land for all known populations of northern leopard frogs identified during the 2005 survey (see Section 7.1, Item \#1).

2. Make application to Alberta Public Lands and Forests Division for protective notations (PNTs) on all northern leopard frog habitats occurring on crown and other publicly owned land.

3. Make contact with landowners/lessees on private or leased land that support northern leopard frog populations to make them aware of the presence of frogs, advise them of recommended land-management practices which enhance survival of northern leopard frogs, and seek opportunities for cooperative management.

4. Direct management of sites to alleviate threats through cooperative agreements with landowners/lessees, or other initiatives.

5. Involvement in referrals (application of appropriate government land-use guidelines) related to industrial or other developments that could potentially impact, affect or degrade northern leopard frog habitat in Alberta.

6. Liaise with the Fisheries Management Branch to ensure that the stocking of game fish does not adversely impact key populations of northern leopard frogs in Alberta, and that knowledge of local fish populations can be used as a factor in assessing the suitability of potential frog reintroduction sites. 


\subsection{Information and Outreach}

1. Conduct a review of potential audiences and possible mechanisms for information delivery about northern leopard frogs and their management in Alberta.

2. Review existing extension information (brochures, web sites, posters, teacher's kits etc.) and assess which products require revision/updating or development.

3. Revise, produce and distribute new extension material as needed. Specific products known to require revision or production include the "Have You Seen This Frog?" poster, a northern leopard frog postcard as an addition to the existing Fish and Wildlife Division postcard series, an updated brochure in the Fish and Wildlife Division/Alberta Conservation Association series, and a Beneficial Management Practices guide for industry and landowners with northern leopard frogs on their property.

4. Provide information on leopard frog-related topics to technical and non-technical audiences through presentations, signage and other mechanisms.

\section{$\underline{7.5 \text { Research }}$}

1. Collect and analyse genetic samples from Alberta, and from other jurisdictions of interest in western Canada/adjacent U.S to provide guidance to reintroduction program.

2. Use geographic information system (GIS) habitat modeling to predict location of sites that may support previously unknown populations, or be candidate sites for reintroduction.

3. Cooperate with all other provincial, national, and international research initiatives that will provide information to better manage northern leopard frogs in Alberta.

\subsection{Plan Management and Administration}

1. Convene the Alberta Northern Leopard Frog Recovery Team a minimum of once annually, and circulate results of these meetings to interested persons.

2. Monitor and assess the progress of recovery plan actions, and develop new recovery strategies and actions when needed (adaptive management).

3. Liaise with other provincial, multi-provincial or international conservation agencies to ensure continuity and flow of information.

4. Enter accumulated population data into the Biodiversity/Species Observation Database (BSOD) and other centralized databases following each field season.

5. Prepare and distribute annual reports on recovery plan activities. 


\subsection{Resource Acquisition}

1. Approach government, non-government and industry partners to participate in or fund leopard frog recovery initiatives.

2. Hire and train seasonal staff to participate in annual field programs, and provide training/orientation to staff of cooperating agencies (government and non-government) when opportunities arise. 


\subsection{IMPLEMENTATION SCHEDULE AND COSTS}

The following table provides a timeline and estimated cost (including direct and "in-kind") for implementation of action items detailed in Section 7.0. It is anticipated that a variety of agencies will participate in the funding and implementation of these activities. $(*)$ denotes that costs are included within other action items, or are part of the daily operations of the identified agencies.

\begin{tabular}{|c|c|c|c|c|c|c|c|c|}
\hline \multirow[t]{2}{*}{$\begin{array}{c}\text { Plan } \\
\text { Section }\end{array}$} & \multirow[t]{2}{*}{ Action } & \multirow{2}{*}{$\begin{array}{c}\text { Lead } \\
\text { Agencies }\end{array}$} & \multicolumn{5}{|c|}{ Cost (thousands/year) } & \multirow[t]{2}{*}{ Total } \\
\hline & & & 2005-06 & 2006-07 & 2007-08 & 2008-09 & 2009-10 & \\
\hline 7.1 & Population/Habitat Monitoring & & & & & & & \\
\hline 1. & 2005 survey & $1,2,5$ & 40 & & & & & 40 \\
\hline 2. & Late summer site surveys & $1,2,5$ & $*$ & 20 & 20 & 20 & 20 & 80 \\
\hline 3. & Spring egg mass surveys & $1,2,5$ & 15 & 15 & 15 & 15 & 15 & 75 \\
\hline \multirow[t]{2}{*}{4.} & \multirow[t]{2}{*}{ New site surveys } & \multirow[t]{2}{*}{$1,2,5$} & 10 & 10 & 10 & 10 & 10 & 50 \\
\hline & & & 65 & 45 & 45 & 45 & 45 & 245 \\
\hline 7.2 & Reintroduction & & & & & & & \\
\hline 1. & Protocol development & 1,2 & 5 & & & & & 5 \\
\hline 2. & Breeding facility & 1,2 & & 25 & 25 & 5 & 5 & 60 \\
\hline 3. & Conduct reintroductions & $1,2,5$ & & 15 & 15 & 15 & 15 & 60 \\
\hline 4. & Assess effectiveness & 1,2 & 8 & 8 & 10 & 15 & 15 & 56 \\
\hline \multirow[t]{2}{*}{5.} & \multirow[t]{2}{*}{ Development of evaluation system } & \multirow[t]{2}{*}{1,2} & 5 & & & & & 5 \\
\hline & & & 18 & 48 & 50 & 35 & 35 & 186 \\
\hline 7.3 & Habitat Management/ Protection & & & & & & & \\
\hline 1. & Site assessments & $1,2,5$ & 10 & 1 & 1 & 1 & 1 & 14 \\
\hline 2. & Protective notations & 1 & 3 & 1 & 1 & 1 & 1 & 7 \\
\hline 3. & Landowner contact & 1,2 & * & 10 & 3 & 3 & 3 & 19 \\
\hline 4. & Cooperative agreements & 1,2 & * & 20 & 10 & 10 & 10 & 50 \\
\hline 5. & Industrial referrals & 1 & 1 & 1 & 1 & 1 & 1 & 5 \\
\hline \multirow[t]{2}{*}{6.} & Liaise with fisheries managers & 1 & * & $*$ & $*$ & $*$ & * & \\
\hline & & & 14 & 33 & 16 & 16 & 16 & 95 \\
\hline 7.4 & Information and Outreach & & & & & & & \\
\hline 1. & Review of potential audiences & $1,2,3,4$ & 3 & & & & & 3 \\
\hline 2. & Review of materials & $1,2,3,4$ & 3 & & & & & 3 \\
\hline 3. & Update, production and distribution & $1,2,3,4$ & 3 & 3 & * & * & $*$ & 6 \\
\hline \multirow[t]{2}{*}{4.} & \multirow[t]{2}{*}{ Presentations } & \multirow[t]{2}{*}{1,2} & 2 & 2 & 2 & 2 & 2 & 10 \\
\hline & & & 11 & 5 & 2 & 2 & 2 & 22 \\
\hline 7.5 & Research & & & & & & & \\
\hline 1. & Genetic analysis & 2,6 & 25 & 25 & & & & 50 \\
\hline 3. & GIS analysis of sites & 1 & 10 & & & & & 10 \\
\hline \multirow[t]{2}{*}{4.} & \multirow[t]{2}{*}{ Cooperate in research } & \multirow[t]{2}{*}{ All } & $*$ & * & * & * & * & \\
\hline & & & 35 & 25 & 0 & 0 & 0 & 60 \\
\hline 7.6 & Management/Administration & & & & & & & \\
\hline 1. & Recovery Team meetings & 1 & 4 & 3 & 3 & 3 & 3 & 16 \\
\hline 2. & Evaluate recovery actions & All Team & * & * & * & * & * & \\
\hline 3. & Liaison with other initiatives & All Team & * & * & * & * & * & \\
\hline 4. & Database management & 1 & 1 & 1 & 1 & 1 & 1 & 5 \\
\hline \multirow[t]{2}{*}{5.} & \multirow[t]{2}{*}{ Annual reporting } & \multirow[t]{2}{*}{1} & 2 & 2 & 2 & 2 & 3 & 11 \\
\hline & & & 7 & 6 & 6 & 6 & 7 & 32 \\
\hline 7.7 & Resource Acquisition & & & & & & & \\
\hline \multirow{3}{*}{$\begin{array}{l}1 . \\
2 .\end{array}$} & Funding securement & 1,2 & 3 & 3 & 3 & 3 & 3 & 15 \\
\hline & Staff training & 1,2 & $*$ & * & * & * & * & \\
\hline & & & 3 & 3 & 3 & 3 & 3 & 15 \\
\hline & TOTAL & & 153 & 165 & 122 & 107 & 108 & 655 \\
\hline
\end{tabular}

${ }^{1}$ Alberta Sustainable Resource Development, ${ }^{2}$ Alberta Conservation Association, ${ }^{3}$ Alberta Environment, ${ }^{4}$ Alberta Agriculture, Food and Rural Development, ${ }^{5}$ Ducks Unlimited Canada, ${ }^{6}$ University of Alberta 


\subsection{SOCIO-ECONOMIC CONSIDERATIONS}

An important guiding principle of the Alberta Northern Leopard Frog Recovery Team is that it will work in a collaborative and cooperative manner with stakeholders to ensure that recovery initiatives for this species are compatible, to the extent possible, with sustainable land uses that support economic activity (see Section 6.2). The Team will therefore strive to minimize the negative implications to Albertans that may result from efforts to recover northern leopard frog populations. On a local level, potential economic costs affecting landholders or land users (e.g., oil and gas developers) may include restrictions on land-use activities, or on timing of these activities. On the other hand, protection and improvements to northern leopard frog habitat may yield economic benefits for leaseholders and landowners through improved water quality and increased productivity of their lands. In addition, conservation and stewardship of habitat for leopard frogs will benefit a variety of other wildlife species and may increase biodiversity in these areas, to the benefit of all Albertans.

There is considerable public interest in northern leopard frogs making this an ideal species for increasing public awareness and support for the conservation of other "At Risk" wildlife and their habitats. Potential ecotourism opportunities may arise from recovery initiatives (e.g., tours of reintroduction facilities and sites).

\subsection{PLAN REVIEW AND AMENDMENT}

The life of this plan is five years. The Alberta Northern Leopard Frog Recovery Team will conduct an annual review of activities to monitor the implementation of the plan and to determine the effectiveness of recovery actions. A report on the results of these reviews will be submitted annually to the Director of Wildlife Management. Recovery plans are considered to be "living" documents and recovery actions can be amended during these reviews, as new information becomes available, as conditions change, or as circumstances warrant. At the end of five years, the Recovery Team will review the overall accomplishments of the plan, discuss amendments to management strategies and actions, and redraft a new plan to be implemented over the next five-year period. 


\section{REFERENCES}

Alberta Environmental Protection. 1994. Natural regions of Alberta. Alberta Environmental Protection, Edmonton, AB.

Alberta Fish and Wildlife Division. 2001. Recommended land use guidelines for protection of selected wildlife species and habitat within grassland and parkland natural regions of Alberta. Alberta Fish and Wildlife Division, Edmonton, AB. 5 pp.

Alberta Sustainable Resource Development. 2003. Status of the northern leopard frog (Rana pipiens) in Alberta: Update 2003. Alberta Sustainable Resource Development, Fish and Wildlife Division, and Alberta Conservation Association, Wildlife Status Report No. 9 (Update 2003), Edmonton, AB. 61 pp.

Ashley, P. E., and J. T. Robinson. 1996. Road mortality on amphibians, reptiles and other wildlife on the Long Point causeway, Lake Erie, Ontario. Canadian Field Naturalist 110:403-412.

Berger, L., R. Speare, P. Daszak, D. E. Green, A. A. Cunningham, C. L. Goggin, R. Slocombe, M. A. Ragan, A. D. Hyatt, K. R. McDonald, H. B. Hines, K. R. Lips, G. Marantelli, and H. Parkes. 1998. Chytridiomycosis causes amphibian mortality associated with population declines in the rainforests of Australia and Central America. Proceedings of the National Academy of Science 95:9031-9036.

Berger, L., R. Speare, and A. D. Hyatt. 1999. Chytrid fungi and amphibian declines: overview, implications and future directions. Pp. 23-33 In: Declines and Disappearances of Australian Frogs (A. Campbell, ed.). Environment Australia, Canberra. 236 pp.

Blaustein, A. R., P. D. Hoffman, D. G. Hokit, J. M. Kiesecker, S. C. Walls, and J. B. Hays. 1994. UV repair and resistance to solar UV-B in amphibian eggs: a link to population declines? Proceedings of the National Academy of Sciences, USA 91:1791-1795.

Blaustein, A. R., and D. B. Wake. 1990. Declining amphibian populations: a global phenomenon. Trends in Ecology and Evolution 5:203-204.

Butterworth, E. W. 1999. A review of the diseases important in decline of amphibian populations with special reference to the necessary protocols required to ameliorate their effects with regards to repatriation of amphibian species. Butterworth E. W. Consulting Ltd. Unpubl. rept. for Alberta Environmental Protection, Wildlife Management Division, Edmonton, AB. 33 pp.

Cook, F. R. 1966. A guide to the amphibians and reptiles of Saskatchewan. Saskatchewan Museum of Natural History Popular Series No. 13, Regina, SK. 40 pp.

Cook, F. R. 1984. Introduction to Canadian amphibians and reptiles. National Museum of Natural Sciences, National Museum of Canada, Ottawa, ON. 200 pp. 
Corn, P. S., and J. C. Fogleman. 1984. Extinction of montane populations of the northern leopard frog (Rana pipiens) in Colorado. Journal of Herpetology 18:147-152.

Corn, P. S., and L. J. Livo. 1989. Leopard frog and wood frog reproduction in Colorado and Wyoming. Northwest Naturalist 70:1-9.

COSEWIC. 2004. Canadian species at risk, November 2004. Committee on the Status of Endangered Wildlife in Canada, Ottawa, ON. 58 pp.

Cottonwood Consultants Ltd. 1986. An overview of reptiles and amphibians in Alberta's grassland and parkland natural regions. Prepared for World Wildlife Fund Canada (Wild West Program), Toronto, ON. 63+ pp.

Cunjak, R. A. 1986. Winter habitat of northern leopard frogs, Rana pipiens, in a southern Ontario stream. Canadian Journal of Zoology 64:255-257.

Dalgleish, T. 2001. Preliminary considerations for the development of a northern leopard frog (Rana pipiens) research and captive breeding program at the Calgary Zoo. For the Calgary Zoo, Alberta Conservation Association and Alberta Sustainable Resource Development. Calgary, AB. $22+$ pp.

Daszak P, L. Berger, A. A. Cunningham, A. D. Hyatt, D. E. Green, and R. Speare. 1999. Emerging infectious diseases and amphibian population declines. Emerging Infectious Disease 5:735-48.

Dole, J. W. 1971. Dispersal of recently metamorphosed leopard frogs, Rana pipiens. Copeia 1971:221-228.

Emery, A. R., A. H. Berst, and K. Lodaira. 1972. Under-ice observations of wintering sites of leopard frogs. Copeia 1972:124-126.

Fahrig, L., J. H. Pedlar, S. E. Pope, P. D. Taylor, and J. F. Wegner. 1995. Effect of road traffic on amphibian density. Biological Conservation 73:177-182.

Fisher, C. 1999. Feasibility of northern leopard frog translocations in Alberta: a review of physiological, ecological, methodological requirements for successful repatriations and results from field investigations. Alberta Environment, Fisheries and Wildlife Management Division, Edmonton, AB. 30 pp.

Fowler, R. L. 1935. Some amphibians and reptiles of the district around High River, Alberta, 1933. Canadian Field Naturalist 48:139-140.

Froom, B. 1982. Amphibians of Canada. McClelland and Stewart, Toronto, ON. 120 pp.

Gibbs, E. G., W. Nace, and M. B. Emmons. 1971. The live frog almost dead. Bioscience 21:1027-1034. 
Hanski, I. 1998. Metapopulation dynamics. Nature 396:41-49.

Hanski I., and M. Gilpin. 1991. Metapopulation dynamics: brief history and conceptual domain. Biological Journal of the Linnean Society 42:3-16.

Hayes, T. B., A. Collins, M. Lee, M. Mendoza, N. Noriega, A. A. Stuart, and A. Vonk. 2002. Hermaphroditic, demasculinized frogs after exposure to the herbicide Atrazine at low ecologically relevant doses. Proceedings of the National Academy of Sciences 99:54765480 .

Hine, R. L., B. L. Les, and B. F. Hellmich. 1981. Leopard frog populations and mortality in Wisconsin, 1974-76. Technical Bulletin No. 122, Department of Natural Resources, Madison, WI. 39 pp.

Hofman, D. E. 1991. 1990 Central region leopard frog inventory. Unpubl. rept., Alberta Fish and Wildlife Division, Red Deer, AB. 8 pp.

Hofman, D. E. 1992. 1992 Leopard frog monitoring project Prince's Spring, Alberta. Unpubl. rept., Alberta Fish and Wildlife Division, Red Deer, AB. 12 pp.

Hofman, D. E. 1994a. 1993 Leopard frog census, Prince's Spring, Alberta. Unpubl. rept., Alberta Fish and Wildlife Division, Red Deer, AB. 12 pp.

Hofman, D. E. 1994b. 1994 Northern leopard frog census, Prince's Spring, Alberta. Unpublished report, Alberta Fish and Wildlife Division, Red Deer, AB. 6 pp.

Hofman, D. E. 1995. 1995 Northern leopard frog census, Prince's Spring, Alberta. Unpublished report, Alberta Fish and Wildlife Division, Red Deer, AB. 6 pp.

Hunter, B. R., D. L. Carlson, E. D. Seppan, P. S. Killian, B. K. McKinnell, and R. G. McKinnell. 1989. Are renal carcinomas increasing in Rana pipiens after a decade of reduced prevalence? American Midland Naturalist 122:307-312.

Johnson, P. T. J., K. B. Lunde, E. M. Thurman, E. G. Ritchie, S. N. Wray, D. L. R. Sutherland, J. M. Kapfer, T. J. Frest, J. Bowerman, and A. R. Blaustein. 2002. Parasite (Ribeiroia ondatrae) infection linked to amphibian malformations in the western United States. Ecological Monographs 72:151-168.

Keisecker, J. M., and A. R. Blaustein. 1995. Synergism between UV-B radiation and a pathogen magnifies amphibian embryo mortality in nature. Proceedings of the National Academy of Sciences USA 92:11049-11052.

Keisecker, J. M., A. R. Blaustein, and C. L. Miller. 2001. Transfer of a pathogen from fish to amphibians. Conservation Biology 15:1064-1070. 
Kendell, K. 2000a. Translocation of northern leopard frogs (Rana pipiens) in the upper Red Deer drainage basin: a comprehensive study on wintering habitat selection of translocated adult leopard frogs near Caroline, Alberta. Alberta Environment, Fisheries and Wildlife Management Division, Edmonton, AB. 52 pp.

Kendell, K. 2000b. Investigation of northern leopard frog (Rana pipiens) over-wintering ecological requirements. Alberta Environment, Fisheries and Wildlife Management Division, Edmonton, AB. 52 pp.

Kendell, K. 2001. Northern leopard frog reintroduction: Raven River - year 2 (2000). Alberta Sustainable Resource Development, Fish and Wildlife Service, Alberta Species at Risk Report No. 13, Edmonton, AB. 43 pp.

Kendell, K. 2002a. Survey protocol for the northern leopard frog. Alberta Sustainable Resource Development, Fish and Wildlife Division, Alberta Species at Risk Report No. 43, Edmonton, AB. 30 pp.

Kendell, K. 2002b. Alberta inventory for the northern leopard frog (2000/2001). Alberta Sustainable Resource Development, Fish and Wildlife Division, Alberta Species at Risk Report No. 44, Edmonton, AB. 29 pp.

Kendell, K. 2002c. Northern leopard frog reintroduction: Year 3 (2001). Alberta Sustainable Resource Development, Fish and Wildlife Division, Alberta Species at Risk Report No. 42, Edmonton, AB. 45 pp.

Kendell, K. 2003. Northern leopard frog reintroduction: Year 4 (2002). Alberta Sustainable Resource Development, Fish and Wildlife Division, Alberta Species at Risk Report No. 78, Edmonton, AB. 15 pp.

Kendell, K. 2004. Northern leopard frog recovery program: Year 5 (2003). Unpubl. rept., Alberta Conservation Association, Edmonton, AB. 14 pp.

Koch, E. G., G. Williams, C. R. Peterson, and P. S. Corn. 1996. A summary of the Conference on Declining and Sensitive Amphibians in the Rocky Mountains and Pacific Northwest. Idaho Herpetological Society and U.S. Fish and Wildlife Service, Snake River Basin Office Report, Boise, ID.

Koonz, W. H. 1992. Amphibians in Manitoba. Pp. 19-20 In: Declines in Canadian amphibian populations: designing a national monitoring strategy (C. A. Bishop and K. E. Petits, eds.). Canadian Wildlife Series Occasional Papers No. 75, Ottawa, ON. 120 pp.

Lannoo, M. J., K. Lang, T. Waltz, and G. S. Philips. 1994. An altered amphibian assemblage: Dickson County, Iowa, 70 years after Frank Blanchard's survey. American Midland Naturalist 131:311-319. 
Leclair, R. Jr., and J. Castanet. 1987. A skeletochronological assessment of age and growth in the frog Rana pipiens Schreber (Amphibia, Anura) from southwestern Quebec. Copeia 1987:361-369.

McKinnell, R. G. 1973. The Lucke frog kidney tumour and its herpevirus. American Zoologist 13:97-114.

McKinnell, R. G., and D. L. Carson. 1997. Lucke renal adenocarcinoma, an anuran neoplasm: studies at the interface of pathology, virology and differentiation competence. Journal of Cellular Physiology 173:115-118.

Merrell, D. J. 1977. Life history of the Leopard Frog, Rana pipiens, in Minnesota. Bell Museum of Natural History, University of Minnesota, Minneapolis, MN.

Merrell, D. J., and C. F. Rodell. 1968. Seasonal selection in the leopard frog, Rana pipiens. Evolution 22:284-288.

Moore, J. E., and E. H. Strickland. 1954. Notes on the food of three species of Alberta amphibians. American Midland Naturalist 52:221-224.

Nace, G. W., D. D. Culley, M. B. Emmons, E. L. Gibbs, V. H. Hutchison, and R. G. McKinnell. 1996. Amphibians: guidelines for the breeding, care and management of laboratory animals. A report of the Subcommittee on Amphibian Standards, Committee on Standards, Institute of Laboratory Animal Resources and National Research Council National Academy of Sciences, Washington, DC.

NatureServe. 2005. NatureServe. NatureServe explorer: An online encyclopedia of life [web application]. Version 4.2. NatureServe, Arlington, Virginia. Available http://www.natureserve.org/explorer. (Access: February 13, 2005).

Pechmann, J. H. K., D. E. Scott, R. D. Semlitsch, J. P. Caldwell, L. J. Vitt, and G. W. Gibbons. 1991. Declining amphibian populations: the problem of separating human impacts from natural fluctuations. Science 253:892-895.

Pessier, A. P., D. K. Nichols, J. E. Longcore, and M. S. Fuller. 1999. Cutaneous chytridiomycosis in poison dart frogs (Dendrobates spp.) and White's tree frogs (Litoria caerulea). Journal of Veterinary Diagnostic Investigation 11:194-199.

Pope, S. E., L. Fahrig, and H. G. Merriam. 2000. Landscape complementation and metapopulation effects on leopard frog populations. Ecology 81:2498-2508.

Rangeland Conservation Service Ltd. 2004. Beneficial management practices for the Milk River Basin, Alberta. A component of the Multi-Species Conservation Strategy for Species at Risk in the Milk River Basin (MULTISAR). Unpubl. rept. prepared for Alberta Fish and Wildlife Division and Alberta Conservation Association. Airdrie, AB. 
Quinlan, R. W., B. A. Downey, B. L. Downey, and P. F. Jones. 2004. MULTISAR: The Milk River basin, a multispecies strategy for species at risk: Year 2 progress report. Alberta Sustainable Resource Management, Fish and Wildlife Division, Species at Risk Report No. 87, Edmonton, AB. 111 pp.

Reichel, J., and D. Flath. 1995. Identification of Montana's amphibians and reptiles. Montana Outdoors 26:15-34.

Rittschof, D. 1975. Some aspects of the natural history and ecology of the leopard frog, Rana pipens. Ph. D. thesis, University of Michigan, Ann Arbour, MI. 212 pp.

Roberts, W. 1981. What happened to the leopard frogs? Alberta Naturalist 11:1-4.

Roberts, W. E. 1987. The northern leopard frog endangered in Alberta. Pp. 137-138 In:

Endangered species in the prairie provinces (G. L. Holroyd, W. B. McGillivray, P. H. R.

Stepney, D. M. Ealey, G. C. Trottier, and K. E. Eberhart, eds). Provincial Museum of Alberta Natural History Occasional Papers, No. 9, Edmonton, AB. 367 pp.

Roberts, W. E. 1991. An action plan for the recovery of the northern leopard frog in Alberta.

Pp. 199-200 In: Proceedings of the Second Endangered Species and Prairie Conservation Workshop (G. L Holroyd, G. Burns, H. C. Smith, eds.). Provincial Museum of Alberta Natural History Occasional Papers, No. 15, Edmonton, AB. 284 pp.

Roberts, W. E. 1992. Declines in amphibian populations in Alberta. Pp. 14-16 In: Declines in Canadian amphibian populations: designing a national monitoring strategy (C. A. Bishop and K. E. Petit, eds.). Canadian Wildlife Service Occasional Papers No. 76, Ottawa, ON. $120 \mathrm{pp}$.

Roberts, W. E. 1994. Amphibian decline? Maybe, maybe not. Environment Network News Jan/Feb:11-13.

Romanchuk, K. A. 2003. Magrath northern leopard frog reintroduction project - year 1 progress report. Alberta Sustainable Resource Development, Fish and Wildlife Division, Alberta Species at Risk Report No. 79, Edmonton, AB. 20 pp.

Russell, A. P., and A. M. Bauer. 2000. The amphibians and reptiles of Alberta. A field guide and primer of boreal herpetology, $2^{\text {nd }}$ edn. University of Calgary Press and University of Alberta Press, Calgary and Edmonton, AB. 279 pp.

Seburn, C. N. L. 1992. Leopard frog project - field report 1991. Unpublished report for World Wildlife Fund Canada and Alberta Forestry, Lands and Wildlife, Edmonton, AB. 59+ pp.

Seburn, C. N. L. 1994. Leopard frog project - progress report 1993. Unpubl. rept. for Alberta Forestry, Lands and Wildlife. Edmonton, AB. 15 pp. 
Seburn, C. N. L., and D. C. Seburn. 1998. Status report on the northern leopard frog (Rana pipiens) in Canada (western populations). Prepared for the Committee on the Status of Endangered Wildlife in Canada. Ottawa, ON. 43 pp.

Seburn, C. N. L., D. C. Seburn, and C. A. Paszkowski. 1997. Northern leopard frog (Rana pipiens) dispersal in relation to habitat. In Amphibians in decline: Canadian studies of a global problem (D. M. Green, ed.). Herpetological Conservation. Society of the Study of Amphibians and Reptiles, St. Louis 1:64-72.

Souder, W. 2000. A plague of frogs: the horrifying true story. Library of Congress Cataloguing-in-Publication Data, New York, NY. 299 pp.

Sparrow, F. K. 1968. Ecology of freshwater fungi. Pp. 41-93 In: The Fungi. (G. C. Gainsworth and A. S. Sussman, eds.). Academic Press, New York, NY.

Turner, B. C., G. S. Hochbaum, F. D. Caswell, and D. J. Nieman. 1987. Agricultural impacts on wetland habitats on the Canadian prairies, 1981-85. Trans. N.A. Wildl. Nat. Res. Conf. 52: 206-215.

Waye, H. L., and J. M. Cooper. 2001. Status of the northern leopard frog (Rana pipiens) in the Creston Valley Wildlife Management Area 1999 for the Columbia Basin Fish and Wildlife Compensation Program, Nelson, BC. 51+ pp.

Wendlandt, M. 1999. Tracking northern leopard frogs (Rana pipiens) to over-wintering locations at two different sites in southern Alberta. Alberta Environment, Fisheries and Wildlife Management Division, Edmonton, AB. 35 pp.

Wendlandt, M., and L. Takats. 1999. Northern leopard frog reintroduction: Raven River-pilot year (1999). Alberta Environment, Fisheries and Wildlife Management Division, Edmonton, AB. 22 pp.

Wershler, C. R. 1991a. Status of the northern leopard frog in Alberta - 1990. Unpublished report by Sweetgrass Consultants Ltd. for World Wildlife Fund Canada (Prairie for Tomorrow) and Alberta Forestry, Lands and Wildlife, Edmonton, AB. 47+ pp.

Wershler, C. R. 1991b. Management plan for the Prince's Spring area of the Remount Community Pasture. Unpublished report by Sweetgrass Consultants Ltd. for World Wildlife Fund Canada (Prairie for Tomorrow) and Alberta Forestry, Lands and Wildlife, Edmonton, AB. $18+$ pp.

Wershler, C. R. 1992a. Northern leopard frog monitoring - 1991. Unpubl. rept. by Sweetgrass Consultants Ltd. for World Wildlife Fund Canada (Prairie for Tomorrow) and Alberta Forestry, Lands and Wildlife, Edmonton, AB. 50 pp. 
Wershler, C. R. 1992b. Prince's Spring rare species monitoring - 1991. Unpubl. rept. by Sweetgrass Consultants Ltd. for World Wildlife Fund Canada (Prairie for Tomorrow) and Alberta Forestry, Lands and Wildlife, Edmonton, AB. 10+ pp.

Wilkinson, L., and S. Hanus. 2003. Researching Amphibian Numbers in Alberta (RANA): 2002 provincial summary. Alberta Sustainable Resource Development, Fish and Wildlife Division, Alberta Species at Risk Report No. 74, Edmonton, AB. 18 pp.

Wilkinson, L., and K. Kempin. 2004. Researching Amphibian Numbers in Alberta (RANA): 2003 provincial summary. Alberta Sustainable Resource Development, Fish and Wildlife Division, Alberta Species at Risk Report No. 83, Edmonton, AB. 22 pp.

Yaremko, L. 1996. Alberta's amphibian monitoring project. Pp. 320 In: Proceedings of the Fourth Prairie Conservation and Endangered Species Workshop (W. D. Wilm and J. F. Dormaar, eds.). Provincial Museum of Alberta Natural History Occasional Papers. No. 23, Edmonton, AB. 337 pp. 


\section{List of Titles in the Alberta Species at Risk Recovery Plan Series}

(as of December 2005)

No. 1 Maintenance and Recovery Plan for Western Blue Flag (Iris missouriensis) in Canada. (2002)

No. 2 Alberta Piping Plover Recovery Plan 2002-2004. (2002)

No. 3 Alberta Peregrine Falcon Recovery Plan 2004-2010. (2005)

No. 4 Alberta Woodland Caribou Recovery Plan 2004/05-2013/14. (2005)

No. 5 Recovery Plan for Ord's Kangaroo Rat in Alberta. (in print)

No. 6 Recovery Plan for Burrowing Owl in Alberta. (in print)

No. 7 Alberta Northern Leopard Frog Recovery Plan, 2005-2010. (in print)

No. 8 Alberta Greater Sage-Grouse Recovery Plan. (in print)

No. 9 Maintenance and Recovery Plan for Western Spiderwort in Alberta 2005-2010. (in print) 

LIBRARY AND ARCHIVES CANADA

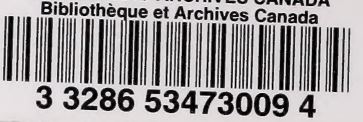

